\title{
The darker side of Fritz Lang's Metropolis: Coloniality in modernist cinema
}

\section{David Golding}

Department of Educational Research, Lancaster University, Lancaster, UK

David Golding

Department of Educational Research

County South

Lancaster University

Lancaster, UK

A1 4YD

\section{Biographical Note}

David Golding is a doctoral candidate at Lancaster University. He has taught development geography, world literature, and peace studies at universities in Sri Lanka. Previously, he worked as a human rights observer in Guatemala and Mexico. His research on coloniality has been published in Journal of Peace Education and elsewhere.

\section{Acknowledgements}

I would like to thank Friedrich-Wilhelm-Murnau-Stiftung and Walter Schulze-Mittendorff @ / WSM Art Metropolis for their permission to use stills of Metropolis and an image of the Machine-Human. I would also like to thank Mtdozier23 of Dreamstime for the photograph of Sigiriya. 


\section{The darker side of Fritz Lang's Metropolis: Coloniality in modernist cinema}

This article situates one of the most influential modernist films, Metropolis (1927), in its relationship to coloniality. The film reflects the Weimar aspiration to recover Germany's place within modernity by securing the boundaries of the colonial difference. More broadly, it elucidates modernity's internal narrative in that it mythically envisions a modernity cleansed of coloniality. Considering that modernity is constituted by coloniality, this paper traces the coloniality from which the film's spiritual anxieties originate. The vertical geography of Metropolis spatialises the relationship between modernity and coloniality as an interiority and exteriority. The spiritual iconography that proliferates throughout the film is haunted by an animist other. This colonial spectre ultimately emerges from modernity's exteriority to possess the commodity fetishes wielded by white men. When the dead labour within the commodities of modernity becomes reanimated through the agency of women and the colonised, both patriarchy and modernity are destabilised. By tracing these significant undercurrents of animist coloniality within the geography and narrative of Metropolis, this paper argues for the decolonial potential of further research that reconsiders modernist cinema and visual art from the perspective of coloniality.

Keywords: Metropolis, modernity, modernist cinema, coloniality, animism, science fiction

Word count: 9,306 


\section{Introduction}

Metropolis (1927) is a German expressionist silent film directed by Fritz Lang and based on a novel by Thea von Harbou. It depicts a speculative urban apartheid between 'the upper-tenthousand', who thrive in a modernist 'Upper City' brimming with opulent playgrounds and sparkling skyscrapers, and innumerate overall-clad machine operators, who dwell below ground in an industrial 'Workers' City'. As will be argued, the Upper City represents the interiority of modernity while the subterranean represents its exteriority. The workers rebel after a possessed gynoid called the Machine-Human gives underground sermons detailing a spiritual-political soteriology. They lay waste to the factory, breach the earth's surface, and run amok through the Upper City. The rebellion is quelled when representatives of the upper-ten-thousand shake hands with those of the workers, who somehow reconsider and accept their subordination.

Metropolis greatly influenced modernism in its attempts to reconcile numerous tensions eminent in late colonial Europe, such as those of state and society, consumption and production, and religion and secularism. As one of the first science fiction films, it is prototypical of cinema's ability to project actually-existing sociopolitical concerns into speculative futures and advance utopian solutions, and is likely the most influential visualisation of the politics and aesthetics of urban dystopias. Its enduring cultural impact led to its inclusion in UNESCO's Memory of the World Register, the first motion picture to hold such a distinction. According to the UNESCO website, Metropolis was chosen as a seminal 'symbol of a (film-) architectural model of the future'. It is therefore particularly emblematic of the European modernist vision of the future as expressed in numerous art forms. Yet despite its historical significance within European modernity, Metropolis has not received scholarly attention from decolonial or postcolonial perspectives. 
This paper locates coloniality close to the very origin of science fiction cinema, which itself is an enduring and increasingly popular progeny of modernism. There is no extant research that explores Metropolis, or for that matter many other modernist European films, as colonial texts. Most scholarship within the field of postcolonial cinema studies focuses its analysis on either texts written with decolonial intentions or those that explicitly depict spaces of coloniality. ${ }^{1}$ Such scholarship rightfully has a central place within postcolonial cinema studies, since representations of colonial spaces are a crucial site in which the colonial difference is reproduced and contested. Postcolonial film theory generally problematises the essentialisation of national and colonial differences in cinema. For example, Stephen Zacks challenges the 'binary distinctions to describe characteristic elements of African and Arab cinema, assuming an essential difference between non-Western and European cinemas and cultures'. ${ }^{2}$ This not only suggests that African and Arab cinemas have been influenced through dialogical encounter with Europe, but also that European cinema has been shaped by African and Arab art and knowledge. Mitsuhiro Yashimoto similarly problematises the differentiation between Western and nonWestern cinemas, going further to dispute the 'Eurocentric view of modernism, which does not consider what modernism possibly means for the non-West' ${ }^{3}$ Likewise, Walter Mignolo observes, 'that coloniality remains difficult to understand as the darker side of modernity is due to the fact that most stories of modernity have been told from the perspective of modernity itself' ${ }^{4}$ Metropolis is one of the most influential representations of modernity produced from within its interiority. This paper therefore situates the film within modernity/coloniality to uncover colonial undercurrents within European modernist cinema.

By contextualising the modernist aesthetic, cultural, and spiritual signs of Metropolis within its late colonial historical moment, this research intends to provoke further studies of 
modernist visual art, and especially cinema, from the perspective of coloniality. Central to this undertaking is Mignolo's theory that coloniality 'is the hidden face of modernity and its very condition of possibility'. ${ }^{5}$ Modern Germany lost its condition of possibility a decade before the production of Metropolis began. The film premiered while Weimar leaders ideated a 'crusade to regain the lost German colonial empire' and thereby secure Germany's inclusion within European modernity. ${ }^{6}$ This crusade sought to recover the coloniality that materially enables modernity and racially enables whiteness. Accordingly, Metropolis maps Jewishness as a threat to modernity that lurks at its racial frontier and harbours a subversive underground interconnection with coloniality. R. L. Rutsky also saw Nazism in the film's modernity because 'it is through Hitler that an alienated, modern Germany is to be reinfused with the eternal German spirit'. ${ }^{7}$ Hitler himself recognized his spirit in the modernity of Metropolis. ${ }^{8}$ Aimé Césaire understands Nazism as a force that 'oozes, seeps, and trickles from every crack' of whiteness. ${ }^{9}$ Within the coloniser, 'that Hitler inhabits him, that Hitler is his demon', a spirit who 'applied to Europe colonialist procedures which until then had been reserved exclusively' for its exteriority. In other words, whiteness hosts the spirit of coloniality. Metropolis unveils this spirit possession and thereby revisualises the racial boundaries that delineate the colonial difference.

To some extent, Metropolis is unmistakably rooted in Weimar thought. Tom Gunning sees the film as 'a text whose allegorical energies seem unable to coalesce into a single grand narrative, but rather ceaselessly generates reference to nearly all narratives_political, religious, occult, aesthetic, sexual — that circulated through Weimar culture'. ${ }^{10}$ The narrative cacophony and its contradictory messages stir a chaos of symbolism, which informs Gunning's observation that 'the energy in Metropolis becomes increasingly centrifugal, images escaping from the grand narratives to which they belong'. However, he overlooks the coloniality at the centre of this 
mystical vortex of narratives. Weimar popular consciousness often narrated the aftermath of World War I and the dismantling of its colonial empire as Germany's own colonisation and expulsion from modernity. The Weimar welfare state intended to reclaim German modernity by incorporating the population under a singular and total demos. By contrast, the Nazi Party harnessed a 'racist biopower' to spatialise a more exclusionary modernity through the reinscription of coloniality onto certain portions of the same demos, facilitated by the dismantling of the Weimar welfare state. ${ }^{11}$ The Nazi Party's genocidal project built upon previous discussions amongst Weimar policymakers that considered the possibility of the internal colonisation of Germany. ${ }^{12}$ The precursors of this exclusionary modernity were also visible in works of Weimar science fiction that romanticised the re-establishment of German colonies to map modernity onto the homeland, including, as argued in this paper, in Metropolis. ${ }^{13}$ As one of the most influential modernist films, and one that explicitly projects a utopian vision for modernity, Metropolis is paradigmatic not only of Weimar values, affects, and anxieties, but more broadly those that circulated throughout modernity itself. Anton Kaes sees Metropolis 'as a historically explainable attempt to fight those tendencies of modernity that have undeniably shown themselves to be cruel and dehumanizing,' although he falls short of identifying modernity's exterior boundaries as the site of such cruelty and dehumanisation. ${ }^{14}$ Like much modernist art, the film grapples with the dissonant experiential qualities of modernity that originate from and ultimately point back to its exteriority, a peripheral other from which its power concentrates, a 'darker side' of modernity. As Mignolo indicates, locating coloniality at the exteriority of modernity does 'not mean something lying untouched beyond capitalism and modernity, but the outside that is needed by the inside.${ }^{15}$ It is therefore argued that a feminised coloniality impinges upon the patriarchal modernity presented in Metropolis. Workers' bodies 
are coded with whiteface and assembled to signify the exteriority of modernity, a process discussed later in this paper. The film employs this double articulation to render coloniality as an absent signifier, a force invisibilised through the technique of whiteface. Coloniality haunts the dystopia depicted at the film's beginning, intimating the white male fear that modernity, coloniality, and patriarchy together have consequences relating to the spirit. These anxieties in Metropolis manifest as colonised and feminised animist forces that transgress the boundaries of colonialism and patriarchy, which intersect in both body and geography.

\section{The vertical geography of modernity}

Metropolis is often regarded as a purely modernist film whose setting represents a 'microcosm' of modern society. ${ }^{16}$ By exploring the vertical geography of its Metropolis, however, it becomes clear that modernity is represented not only temporally but also spatially. Just as Mignolo challenges the temporal imaginaries of coloniality and modernity by spatialising them, so too does Metropolis arrange a spatial dualism, albeit without losing its temporal tenor, between the Upper City and the Workers' City beneath. The film is rooted not merely in modernism but also colonialism, and thus it will be argued that certain segments take place wholly outside Metropolis, in spaces beyond modernity.

At its summit of the Upper City stands the Club of the Sons, a complex amongst the clouds whose architecture borrows from the coliseums of Classical Greece. Here we are introduced to Freder, the film's white male protagonist who, like the others at the Club of Sons, wears only white. Replete with 'its lecture halls and libraries, its theaters and stadiums' as described in the film, the Club of the Sons is a site in which the men of the upper-ten-thousand cultivate Aristotelian excellence through not only cultural pursuits, but also athletic pursuits in 
the stadion visually depicted in the film. Alex McAuley argues that "the "Club of the Sons" represents Olympus, and thus the wealthy elite have become the gods on high'. ${ }^{17}$ The Club concretises the European creation myth by which Mignolo says 'modernity (and obviously postmodernity) maintained the imaginary of Western civilisation as a pristine development from ancient Greece to $18^{\text {th }}$-century Europe, where the bases of modernity were laid out'. German conceptions of modernity have traditionally borrowed from the Greek imaginary, particularly 'the second stage of modernity [which] was part of the German restitution of the Greek legacy as the foundation of Western civilization'. ${ }^{18}$ The spatial and cultural epitome of modernity represented by the Club of Sons resembles less a capitalist elite than an idealisation of European culture.

Visually darker than and spatially underneath the Club of Sons is the Eternal Garden, a conservatory in which female sex workers indulge the fantasies of wealthy white men. Depicted through sketches that detail a botanical orientalism, the gardens brim with surreal alien flora based on plants from a miscegenated tropical biome, including baobab-like tree stands, aloe, and oversized dracena. The dense tropical foliage is permeated by pathways of manicured grass adorned with egrets, peacocks, and minimalist deco fountains. The domestication of a savage female wilderness through its penetration by arteries of European male virility resonates with patriarchal modernist narratives of colonial spaces. The ecologically tamed pathways that lace the Eternal Garden provide sites in which male heterosexual desire can be domesticated while still maintaining access to a colonial-coded feminine space of wild tropical vegetation. Gabriela Stoicea highlights the objectification of the sex workers into their embodied tropical environment in that 'with their attire and demeanour, the prostitutes blend into the decor of the Eternal Garden', particularly when they entertain Freder 'under a cavernous canopy that resembles the 
sculptural shape of the prostitutes' skirts'. ${ }^{19}$ The woman-objects animate the tropical environment by prancing before Freder in eclectic garb such as tricorns and Victorian court mantuas. Although they are racialised as white and wear distinctly European attire, their location within a tropical conservatory encapsulates coloniality as a domesticable space of white male freedom and fulfilment.

The lowest space within the Upper City's vertical geography is likely Yoshiwara, a nightclub which appears somewhat more feminised and colonised than the Eternal Gardens through its fusion of European hedonism and orientalism, violins and paper lanterns, roulette and geishas. Jürgen Müller notes the purely white population of the Upper City and that 'Yoshiwara, by contrast, is presented in several passages as a place of prostitution and promiscuity—a semantic field to which racial mixing can be added ${ }^{20}$ Barbara Mennel more specifically interprets that, as the only setting where Metropolis explicitly depicts people of colour, 'Yoshiwara is associated with the feminine and the Orient, echoing the notion of adventure capitalism.${ }^{21}$ As with the rest of the Upper City, women are bodies without agency from which heterosexual labour is extracted. The geographic subordination of Yoshiwara as the lowest realm within modernity is also established through its shadowy mise-en-scène and, as will be discussed later, when it becomes the site where modernity is breached by its exterior population.

[Figure 1]

The Upper City's modernity and its contradictions generate anxiety amongst its inhabitants, and especially within Freder. After witnessing for himself the horrors of the Workers' City, he returns to the earth's surface clutching his head as he spiritually grapples with 
the awareness that the Upper City is built atop a machine of injustice. The machine is controlled by his father, Fredersen, from the top floor of the New Tower of Babel using an array of levers, meters, readouts, CCTVs, and control panels. He gestures across the sunlit cityscape, 'your magnificent city, Father — and you the Brain of this city — and all of us in the light of this city'. Freder is confronted with the unsettling contradictions of light without darkness, consumption without production, European industrialisation without inputs, modernity without an exteriority. He asks his father, 'where are the people, Father, whose hands built your city?' Fredersen responds, 'where they belong'. Dismayed, Freder specifies, 'in the Depths?', which his father affirms. Feder's eyes widen as if he were perceiving a mystical reality beyond the city, beyond modernity, as he questions, 'what if one day those in the Depths rise up against you?' This social discordance becomes internalised within Freder's mind and later destabilises the colonial difference that structures the film.

[Figure 2]

The critical geography of Metropolis maintains the colonial difference - that is, the absolute separation of a self-contained Europe from coloniality—by eschewing explicit representations of coloniality as the cultural and material enabler of modernity. Freder apparently struggles with a cognitive dissonance particular to the schizophrenia of capitalist culture: European modernity is experienced as ontologically complete, and yet its boundless consumption and abundance suggest a corresponding production and deprivation elsewhere. Metropolis ostensibly locates this production, deprivation, and oppression in a subterranean working-class. The darker side of the Upper City manifests as the factory, hidden from the very city planners 
who enjoy its wealth and presumably have the power to liberate the oppressed. The obscurity of the Workers' City is suggestive of Karl Marx's theory of the capitalist abstraction of power, which Wendy Brown summarises: 'Where commodities appear in the marketplace, they do not manifest their production process or relations. That is, they don't reveal the extraction of surplus value from labour that generates their value'. Spaces of consumption are divorced from 'the hidden abode of the production, which, [Marx] notes, is marked by a "no trespassing" sign'. ${ }^{22}$ From this perspective, Freder's infiltration of the Workers' City marks his acquisition of a revolutionary class consciousness. The overtly Marxist thematics in Metropolis explain why Müller, like many others, discusses the film's attempt 'to lend expression to this discomfort with a liberal, democratic modern era' as primarily relating to capitalism. ${ }^{23}$

Expectedly, the film's initial audiences in Berlin interpreted its political message as operating through class. On those grounds, early critics lambasted the perfunctory solution to class antagonisms Metropolis presents at its conclusion, in which the upper-ten-thousand and the workers reach an accord that maintains their geographic and political apartheid. ${ }^{24}$ For an audience within the Weimar Republic's somewhat robust civil society, the film's utopian vision in which the workers meekly accept their oppression was repugnant because the audience imagined the proletariat to be included within the demos of modernity. ${ }^{25}$ In other words, the audiences in Berlin could not accept that the workers remained outside of modernity at the film's utopian conclusion because the workers were depicted as white. Yet the subterranean workers cannot be said to be included within the demos of modernity since, as McAuley observes, 'the workers of the film seem to be less than fully human, given their lack of individuality and absence of socialization'. ${ }^{26}$ Even further from the demos are the women of the Workers' City, whose lives are confined entirely to a domestic sphere in which their labour is extracted. Those 
in the Workers' City live closer to hell than to heaven, visibly shrouded in the darkness of ignorance, far from the Upper City's white luminescence, backwards and downwards along the vertical timeline that the film spatialises.

The vertical geography of Metropolis hides the spaces of production from the spectacle of the market, and furthermore conceals the coloniality of that production from modernity. Mignolo contends that 'Marx also remains within the macro-imperial narrative because he misses the colonial mechanisms of power underlying the system he critiques', which suggests that coloniality give impetus to the politics of Metropolis precisely because its Marxist undertones are so prevalent. Mignolo elaborates that just as modernity and coloniality are mutually constitutive, 'the modern/colonial world cannot be conceived except as simultaneously capitalist'. He specifies four articulations of this capitalist coloniality, which together enable the dominion of white heterosexual men over political power, gender, sexualities, truth-production, and land. Seized by the 'colonial matrix of power', the subterranean Workers' City is devoid of land, external to the 'Brain' that produces truths, the only space accessible to women who survive by means other than paid sexual labour, and therefore constitutes the exteriority of patriarchal modernity. ${ }^{27}$

\section{Subterranean coloniality}

Metropolis embodies the problematic of modernity and its exteriority not only as the proletariat, but also as the colonised. In expressionist fashion, the film engages with coloniality indirectly through aesthetic and symbolic interplay. The impoverished white men in the Workers' City wear dark coveralls that distinguish them from the white-clad upper-ten-thousand, and are subsumed by shadow within the machinic obscurity of their subterranean city. In this sense, 
Metropolis pioneered a racial coding technique that would later proliferate throughout film noir. Eric Lott sees film noir as a 'whiteface dream-work of social anxieties with explicitly racial sources, condensed on film into the criminal undertakings of abjected whites', often achieved through filmic signifiers such as the use of white and black in the mise-en-scène, the casting of shadows across the skin of white bodies, and the thematic of social 'darkness' at the periphery of modernity. ${ }^{28}$ After Metropolis, Lang directed some of the earliest and most influential noir films such as Fury (1936), which centres on the lynching of a white man. Mennel argues that Fury employs whiteface by transposing race-based violence into a whitened victimhood. ${ }^{29}$ Coloniality in Metropolis is similarly embodied in whiteness and biologised in the metaphor repeated throughout the film: the workers are the 'Hands' and the upper-ten-thousand constitute the 'Head'. Using Christian iconography, the film depicts the modernity's requirement of an exterior biopower with the phrase 'those who had conceived of the Tower of Babel could not build the Tower of Babel. The task was too great'. The next line, 'the Hands that built the Tower of Babel knew nothing of the dream that the Brain had conceived', projects a biological role of manual rather than intellectual labour onto those at modernity's exteriority.

Throughout the film, the 'Heads' grapple with whether they should regard their 'Hands' as part of their own body, rather than colonising them as an exterior space of extraction, exploitation, and production. Metropolis introduces this problematic with the entrance of Maria, a figure of moral purity who acts as a Christian missionary below ground. In a spectacle of poverty, Maria guides a mass of orphaned children up from the Workers' City, across the colonial difference, and into modernity. She gestures towards Freder and the sex workers in the Eternal Garden and explains to the children, in the film's most radical statement, 'look! These are your brothers!' She then stares into the camera, which places the audience within Freder's 
gaze, and addresses him directly. She repeats, 'these are your brothers!' Since she now speaks to Freder, her reiteration implores Freder to see the humanity of the children who have been excluded from modernity. This awakens in Freder the subversive revelation that the workers are his 'brothers', the word which Freder uses to refer to the workers throughout the rest of the film. Maria's declaration makes little sense in reference to the proletariat, who in modernist European thought never had their membership within the human race questioned. Instead, the children here represent the population on the exteriority of modernity, reproducing the historically prolific image of the colonised as children in need of guidance. Positioned front and centre, her all light garb contrasting with the dark rags of the huddled masses, Maria purposefully stares forward with a determination signifying the coloniser's responsibility to bring the rest of humanity towards progress. Modernity's contradictions are eventually rectified when Freder accepts his role as the 'Heart' that mediates between the Head and Hands. Like the colonised, the workers are not fully human and thus are incapable of participating directly in the demos. Instead, they require a 'mediator' between themselves and imperial power, placing Freder in a position akin to a colonial officer. The racial difference between Freder and the workers is especially apparent when the workers disparage him as 'the dog, in his white-silken fur', referencing the contrast between their own whitefaced bodies and the pure whiteness of the upper-ten-thousand's skin, attire, and environment. The word used in the original German intertitle, Fell, can refer to either animal fur or human skin. The use of class disparities to signify a more significant division is also alluded to when Freder's father terminates the employment of a man who had, until then, been part of the upper-ten-thousand. Freder protests, 'Father, do you know what it means to be dismissed by you? It means: Go below! Father-Go below! Into the Depths!' In other words, it means to be expelled from modernity. 
Coloniality in Metropolis is a subterranean space of exploitation and production that enables the modernity above. Lang's association of subterranity with coloniality was established three years prior to Metropolis in another film he directed, Die Nibelungen (1924), which had particular influence on Adolf Hitler. Die Nibelungen arranges vertical elements to spatialise an even more explicitly racialised white supremacy. Susan P. Bratton identifies its protagonist as a 'natural Aryan knight' who is depicted 'as a product of a highly dramatized German landscape', much like the upper-ten-thousand who have naturally inherited the earth's surface. The spatial elevation of modernity above primitive coloniality is likewise seen in Die Nibelungen, which 'divides humanity into those who are ascendant, and thereby associated with "good" nature, and those who are degenerate, and associated with the subterranean and slimy'. Specifically, the subterranean are dwarves laden in loincloths and beaded necklaces, their chests covered in special-effects fur to lend them an animalistic appearance. Led by a king named Alberich, they eat while sitting on the forest floor and regard the world with imbecilic bewilderment. Paralleling the New Tower of Babel in Metropolis, the Aryans in Die Nibelungen live in a towering castle where they preserve their technologically advanced, culturally detailed, and distinctly Catholic society. The vertical hierarchy of modernity/coloniality again appears when employing 'verticals repeatedly to enhance Siegfried's superhuman status, Lang presents a dwarf king who is not just short, but has a hooked nose, crooked fingers, a hunched back, and a chimpanzee-like walk'. Alberich's Jewish physiognomy corresponds to the primitivism and savagery inscribed onto his dwarves. Their temporal exclusion from modernity is particularly apparent in the film's narrative aesthetic: 'The hero strides across the sets like Cro-Magnon evolutionary advance pulling itself away from the vestigial Neanderthal lineage'. The primatial and enfeebled figure is effortlessly slain by the fully-human Siegfried. In Bratton's analysis, 'Lang casts Alberich as an evil shadow 
of the supernatural, easily destroyed by Siegfried's “modern” technology'. As with the upper ten-thousand in Metropolis, who secure their dominion over the earth's surface by naturalising their paradoxical superiority over and harmony with the workers, 'Siegfried's capture of the wealth of the earth is linked to his superiority over the dwarves'. Although the workers in Metropolis are portrayed as white bodies by white actors, their subterranean location external from the metropolitan demos aligns with Lang's vertical geography of coloniality and modernity seen in Die Nibelungen. ${ }^{30}$

Beneath the colonial machinery that animates Metropolis lies an even more primordial space, the 'Catacombs'. They are unequivocally external to Metropolis since Freder refers to 'the 2000-year-old Catacombs deep below the lowest levels of your Metropolis'. Peter Ruppert therefore refers to the Catacombs as a 'third space mapped out in the film, a pre-technological space'. ${ }^{31}$ They are accessed by a trapdoor in the basement of a Gothic house. The intertitle reads: 'In the middle of Metropolis is a strange house, overlooked by the centuries'. This spatially malignant and temporally backwards structure occupies the heart of modernity, its dark and steeped roof juxtaposing with the skyscrapers illuminated in the background. It is home to Rotwang, an evil Jewish-coded scientist-sorcerer at the racial frontier of the Upper City. Rotwang himself is portrayed with what Kaes calls a 'categorical outsider status by linking him to a bizarre-looking medieval house surrounded by huge skyscrapers. Inventor of the artificial human machine, as well as sorcerer and magician, Rotwang represents the archaic and nonsynchronous dimension of modernity' ${ }^{32}$ This racially liminal space conceals a passage that interconnects with The Catacombs, a dark maze of skull-lined corridors and crumbling staircases leading to a vast cavern with primitivist architecture. At the centre is a pulpit backgrounded by rudimentary crucifixes, from which Maria preaches a liberation theology to the workers. Claudia 
Springer thus contends that 'this feminized space exists far below the surface of the earth because, in psychoanalytic terms, female sexuality has been deeply repressed in the city of Metropolis.${ }^{33}$ The Catacombs are feminised in both their distance from Fredersen's capitalist patriarchy and their apparent privileging of matrilineal knowledge. However, a solely genderbased interpretation of the Catacombs as feminine neglects its near-complete population by male bodies, its temporal backwardness, and its spatial exteriority from modernity.

[Figure 3]

Beyond the machinery of the Metropolis, the Catacombs constitute a distinctly subaltern space. Modernity requires the economic inclusion of coloniality while it continually reproduces the political exclusion of coloniality from the demos. Modernity delineates these contradictory boundaries by bifurcating coloniality into a division that Mignolo calls 'an interior exteriority and exterior exteriority, ${ }^{34}$ The Catacombs, beyond modernity's imperial control, are an exterior exteriority in which the oppressed find spiritual autonomy and formulate a counter-public. From the pulpit, Maria unveils to the workers their own origin with the Legend of the Tower of Babel. Just as the Head needs the Hands to realise its designs, the upper-ten-thousand requires an exterior population to build Metropolis, so 'they hired foreign Hands for Wages'. The wages, however, remain entirely unseen in Metropolis, suggesting that the interrelationship between the upper-ten-thousand and the 'foreign' workers is existentially rather than economically generative. Frantz Fanon similarly writes that 'it is the settler who has brought the native into existence and who perpetuates his existence. The settler owes the fact of his very existence, that is to say, his property, to the colonial system' ${ }^{35}$ The Catacombs therefore reify Andrew 
McCann's speculation that the modernist project to eradicate animism is haunted by the 'deathwish at the heart of colonial modernity: the city of the future built on corpses-indeed a savage metropolis' ${ }^{36}$ From this perspective, the Workers' City is an interior exteriority that innervates modernity, while the Catacombs are the exterior exteriority from which emerge all resistances to and possibilities beyond modernity/coloniality.

Metropolis is an attempt to rectify the political dangers of modernity by recoding coloniality as white, thereby enclosing modernity within a self-contained and racially homogenous polity. The coloniality upon which modernity relies is recast in the classical Marxist terms of labour exploitation, and the dead labour that haunts its modernity is imagined to be white and male. However, when this same dead labour reanimates itself to possess the commodity fetishes of Metropolis, it regains its true form as a colonised and feminised insurrectionary force.

\section{Colonised and feminised animism}

The detailed geographic structure of Metropolis and its exteriority constitutes a microcosmology in which social, religious, and animist representations can be rearranged and reinterpreted to explore the crises of modernity/coloniality. The film's combination of mythical worldbuilding and mystical symbols reterritorialises the domain of spirits, which had historically been relegated to an animist coloniality, into a European space. Harry Garuba theorises that 'animism is the spectral Other that simultaneously constitutes and haunts the modern' in that it 'has functioned as the metaphoric receptacle for everything that is a negation of the modern' ${ }^{37}$ McCann describes the 'atavistic' emergence of animism from within modernity: 
If enlightenment effects the 'disenchantment of the world' through the 'extirpation of animism', it also reproduces the very conditions it sought to surmount as its own sovereignty, apparently opposed to myth and committed to formal rationality, is more deeply engulfed in mythology the more total its power becomes. ${ }^{38}$

When reconsidered from the perspective of coloniality, Metropolis reflects a European mythology of modernity. Through its syncretism of industrial rationalism, ecclesiastical iconography, and pagan mysticism, this mythology paradoxically attempts to exorcise the animist coloniality from modernity and reenchant its commodity fetishes that are already territorialised by patriarchal whiteness.

The film's prevalent oneiric imagery elevates Metropolis to a mystical realm, transcendent of space, in which universal truths can be established. Richard Murphy argues that the hallucinatory qualities of Metropolis epitomise an expressionist aesthetic in which the destabilisation of perspective envisions a universalist gaze and its spiritual tensions. He gives the example of a 'stunning composite montage-image $[. .$.$] depicting only the staring eyes of the$ young men pictured simultaneously from a multitude of perspectives and distances in such a fashion that it could only be "dreamt" but not "seen". For him, this sequence subjectifies a disoriented yet universalist gaze because 'the two perspectives are difficult to reconcile, and they produce a division in the spectator, for how can the scene be both subjective and objective, internal and consensual?' Without connecting the anxieties of modernity to its colonial exteriority, Murphy cites the film's phantasmagorical aesthetics as exemplary of the 'modernist movement's literary response to modernity' because in 'a world felt to be increasingly chaotic, overwhelming, and out of control, the sense of narrative authority and epistemological stability associated with the mode of classic realism was clearly unsuitable'. ${ }^{39}$ Similarly, Steven Jacobs 
argues that the schizophrenia of Lang's films originates in the multiplicitous gazes and subjectivities that permeate modernity's urban panopticism, which constructs the nocturnal city as a mystical space of fragmentation, phantasmagoria, and magic. ${ }^{40}$ The universalist gaze established by the film's expressionist aesthetics regards both the spiritual limits of modernity and the animism that extends beyond those limits. Daniel L. Selden sees the universalist gaze as characteristic of European cinema's 'peculiar mode of forming a transcendental subject where seeing is possessing for an eye liberated from localized particulars to invest its vision — which is to say its ownership — elsewhere (in Africa, in Asia, in Australia, in South America) ${ }^{41}$ Metropolis is not just aesthetically but narratively universalistic in that Metropolis is deracinated into a mythical microcosm of modernity and its exteriority. Metropolis, then, is set within a Europeanised elsewhere in attempt to recover an alienated animism from spaces of coloniality. Amidst the film's saturation of pagan, spiritual, and animist signifiers, Moloch and the Machine-Human stand out as the two spirit-beings that engage most directly with coloniality in that they channel agency from human labour at the exteriority of modernity. As I will illustrate in this section, they both exemplify Caroline Rooney's observation that “"the remnants of animism", so to speak, that I would affirm can be found in Western art and culture are idiosyncratic, deracinated and sometimes symptomatic of an alienated consciousness'. As anthropomorphic commodity fetishes, they both embody modernity's greatest fear: that 'animism, the undeniability of living spirits and the living on of spirits, can but keep not so much "returning" as continuing, however much denied', and thus that modernity is haunted by spirits that continue to act despite the desecration of the colonised bodies they once inhabited. Animism in Metropolis is manifested according to the coloniser's universalist gaze as it surveys coloniality. Nevertheless, the narrative arcs according to spirits that begin to transgress the 
colonial difference and possess the Upper City, supporting Rooney's argument that 'while "animism" may refer to an inscription of an affirmation or thinking of spirits within African culture, but not only African culture, it also refers to what a Western intellectual culture tries to deny, disallow, disavow, discredit'. In Metropolis, animism is coded with both signs: an orientalist marker of colonised ontologies and a denial of modernity's spiritual dimensions. ${ }^{42}$ Scholars have often argued that the subjugation of workers' agency in Metropolis indicates the secular rationalism of industrial modernity, overlooking the role of spirits in animating the industry of Metropolis. Andreas Huyssen understands the machinery that permeates Metropolis as emblematic of the modernist 'notion of a blindly functioning world machine, a gigantic automation' which signalled that 'the determination of social life by metaphysical legitimations of power was replaced by the determination through the laws of nature'. ${ }^{43}$ He gives the example of the repeated depiction of workers wrestling not with the levers of a control panel that transmits human agency into machinery, but rather with the steel arms of an industrial-scale clock that flexes and stretches human limbs according to some unseen machinations. Reflecting on these scenes, Michael Cowan notes that 'modernization, here, appears as a process entailing the temporal disciplining of the body through a regime of industrial Takt, where the body's natural rhythms are subordinated to the rhythms and the tempo of the industrial clock'. He alludes to the colonisation of time when he contrasts the modernity of Metropolis with 'traditional societies [that] had used the body's rhythms to guide the tools of labor', whose subjugation under modern/colonial temporality engenders the draining of agency from coloniality and its concentration within modernity. ${ }^{44}$ Huyssen and Cowan's purely materialist interpretations of the reversal of agency between worker and machine fail to account for Moloch, the industrial deity that distributes its will throughout the motors and gears of 
Metropolis. Gunning comes close to recognising the animism that haunts the modernity of Metropolis when he identifies that 'the allegorical centre of Metropolis lies in the revelation of a demonic energy at the core of the rational system of modern technology', but his explanation falls short of locating Moloch as its source..$^{45}$

Moloch, whose namesake is a Canaanite god associated with fire and the sacrifice of children, is a wrathful spirit who steals life from the workers and bestows it upon the sprawling mechanical corpus of Metropolis. Its appearance is described by Murphy as 'the anthropomorphosed monster of technology, the "Moloch", devouring workers'. ${ }^{46}$ Moloch's anthropomorphism reconciles secular modernity with its animist hauntology because, as Russell Belk and Mariam Humayun indicate, object agency is often experienced in modernity as commodities vitalised by 'contagious magic, as well as anthropomorphism, animism, [and] fetishism.${ }^{47}$ Freder's own spiritual awakening begins with a mystical encounter with Moloch's avatar. He directly perceives Moloch's agency when he watches the machinery cruelly malfunction, singeing workers with steam and ejecting their bodies through the air. In the mists that rise from the carnage, Freder witnesses the materialisation of Moloch, whose gargantuan turbine enclosures have become twin paws that straddle a staircase in close resemblance to the Sri Lankan rock fortress Sigiriya. Moloch's visage features repeated protruding lines around the eyes and lips to evoke a culturally deracinated appearance that, in orientalist fashion, seemingly references masks of various indigenous origins. Two ceremonial soldiers in primitivist attire oversee the forcible sacrifice of the mostly-naked workers. The workers are marched up the temple steps and cast into the churning machinery within the maw of Moloch. The anthropomorphic depiction of the machinery of Metropolis as a being that gains life by depriving workers of their own is echoed later in the film, when the Machine-Human instigates revolution 
by asking the workers, 'who lubricates the machine joints with their own marrow?! Who feeds the machine with their own flesh?! Let the machines starve, you fools! Finish them off!' Later, they celebrate their freedom by dancing around the flaming scrapheap of Moloch's corpse.

Moloch's appetite for humans mirrors that of Cerro Rico de Potosí, the Bolivian mountain rich with silver in whose mines eight million indigenous and black slaves were worked to death by the Spanish crown. Eduardo Galeano recounts its anthropomorphic reputation as 'the mountain that eats men', which impelled the $16^{\text {th }}$ century monk Domingo de Santo Tomás to inform "the Council of the Indies that Potosi was a "mouth of hell" which swallowed Indians by the thousands every year'. Aberrated by the evils of colonialism, the animus of Potosí likewise turned evil, reflecting the coloniser's reliance upon the enslavement and consumption of the colonised. Beside Cerro Rico looms 'Huakajchi, meaning in Quechua "the cerro that has wept"'. A silent witness to coloniality, tears spring up from Huakajchi's peaks and trickle in streams down its slopes. In Metropolis, Moloch gives agency to the evils of modernity, witnessed not by Huakajchi but by Freder. Although machinery is Moloch's distinct domain, he is the entity that most closely resembles a force of nature in a film whose total whiteness and total industrialism exclude two of its material and spiritual requisites — the colonised and the natural world —in its self-enclosed and patriarchal utopia of modernity. ${ }^{48}$

[Figure 4]

[Figure 5] 
While Moloch subsumes the agency of the workers by devouring them whole, the Machine-Human is a fetishistic spiritual vessel that harnesses their decolonial vocation into a liberatory spiritual force. The Machine-Human's spatial origin is Rotwang's house, discussed in the previous section of this paper as a Jewish racial aberration within the Upper City's modernity. Kaes emphasises that its primitivism and backwardness imbricates with the film's association of 'machines with man-eating monsters and the inventor Rotwang with black magic ${ }^{9}{ }^{49}$ Rotwang's house is possessed by a spirit who channels powers through pentagrammic sigils on its doors to open, close, and lock them. In its dark laboratory, Rotwang harnesses the power of modern science to fabricate a fully commodified human, one of the first robots depicted in film, an anthropomorphic fetish animated by the dead labour of the colonised. The manufactured woman sits at the base of a pagan pentagram, a fetishistic body whose femininity is positioned within a docility at the nexus of colonialism and patriarchy. Rotwang's letter to Fredersen boasts that it 'is the most perfect and most obedient tool which mankind has ever possessed!' This sentiment substantiates Huyssen's argument that Rotwang invokes 'male magic' to produce a woman-object that is utterly subordinate to modern man and enable Rotwang and Fredersen's plan to extend this subordination throughout the exteriority of modernity with an effort to 'replace inherently uncontrollable living labor by robots' ${ }^{50}$ Heidi J. Nast likewise discusses the machinery in Metropolis as a reification of white male power that instrumentalises 'competitive and misogynist desires to reduce, control, displace, and eliminate the biological-maternal (and hence humanity-itself) ${ }^{5}{ }^{51}$ Therefore, Metropolis is not content with merely invisibilising the colonised and the natural world to reenchant modernity as exclusively white and industrial. It also aspires to the erasure of yet another of its origins, women, so that men generate life on their own terms. 
The Machine-Human's animist significance is revealed in the second stage of its conjuration, when Rotwang sequesters Maria into his laboratory and connects her anesthetised body to the Machine-Human, thereby creating what scholars often term a 'false Maria'. Huyssen deconstructs this scene in terms of the sexual politics of female objectification and male subjectification, contending that 'first Rotwang constructs the mechanical "inner" woman; external features such as flesh, skin, and hair are added on in a second stage when the body features of the real Maria are transferred to or projected onto the robot'. Rotwang thus 'filters her sexuality out of her and projects it onto the lifeless robot who then comes alive as the vamp Maria ${ }^{52}$ However, a closer reading of the spirit possession operating in this scene reveals that the Machine-Human exists not within the human shell of Maria, nor is it merely Maria's sexuality that animates the Machine-Human. Rooney defines spirit possession 'as an embodied enactment: a living out of this spirit or that spirit. It is, in effect, a creative performance but not so much as a mere mimicking of something as a captivation by it ${ }^{5}{ }^{53}$ False Maria is thus not a mimetic replica, but rather represents the possession of the Machine-Human by the spirit of all that Maria embodies. As Maria's animus enters the Machine-Human, a light begins to pulse at its heart, signifying its captivation by Maria's entire spirit. Maria's animus possesses the MachineHuman with the dead labour of the colonised, previously enunciated as an anti-patriarchal and anti-colonial spirit from her pulpit in the Catacombs, her animist domain at the exterior exteriority of modernity.

[Figure 6] 
The possessed Machine-Human embodies an atavistic animism that fetishistically moves with the agency of dead labour and breaches into modernity from its exteriority. Through her, the colonised and feminised object reclaims its own subjectivity. She earns the label of 'witch' because she moves through her own animus despite man's attempts to transmogrify her into dead labour. As is typical in the white male narrative of witchcraft, the possessed Machine-Human's feminised and colonised standpoint grants her fluency in the heterosexual male code of desire, which is objectification; modernity's code of desire, which is consumption; and coloniality's code of desire, which is liberation. She initiates the upheaval of patriarchal modernity by performing an erotic dance in the Yoshiwara nightclub before a gathering of the men of the upper-ten-thousand. Huyssen identifies that the false Maria's 'sexuality posing a threat to male rule and control, which is inscribed throughout the film, corresponds precisely to the notion of technology running out-of-control and unleashing its destructive potential on humanity' ${ }^{54}$ Also embedded within this technology-femininity imaginary is the coloniser's fetishistic fear that the technology of modernity is imbued with the spirits of colonised labour that produced it, and thus harbours a latent agency to upturn the colonial difference. Cowan highlights the way in which the Machine-Human's dance references a French science fiction film from the same era. In L'Inhumaine (1924), a 'heart machine' - aesthetically similar to the one in Metropolissymbolises the subordination of the feminised and colonised body's 'exotic rhythms' to a masculine European technology. The titular protagonist of L'Inhumaine performs 'bizarre soirées, in which black performers dressed in tribal attire entertain her with rhythmical dances, filmed in chaotic accelerated montage sequences' until she dies and is reanimated using the machine. ${ }^{55}$ Evident in both films is McCann's notion that 'the colonial uncanny offers the animistic as a source of pleasure' in addition to fear. ${ }^{56}$ Similar permutations of colonised 
femininity and fetishistic reanimation appear in Metropolis when the female body of the Machine-Human dances before leering men at the Yoshiwara nightclub. Not only is feminine sexuality objectified into a consumer good, but the animation of its fetishised body releases animist spiritual currents that flow up from beneath the metropolis/metropole to flood modernity.

The possessed Machine-Human entrances the white male gaze and then subverts its own objectification by embodying a modernity visibly supported by coloniality. On Yoshiwara's stage, black bodies adorned with loincloths and simple jewellery kneel to support the weight of the ornate pedestal from which the possessed Machine-Human emerges. The pedestal is revealed to be a censer as its circular lid opens and the possessed Machine-Human rises from within. Her skin, robe, and headdress are brilliantly white, emphasised by white mist rising behind her. Her face is centred within the lid, lines emanating outwards like meridians on a globe, pure Mediterranean whiteness at the centre of the world. The immobility of the human platform stabilises the world order atop which modernity expresses itself. Afterwards, the black bodies turn to stone. No longer discrete living beings, they become fused with the sculpture, carved as part of the pedestal itself. Their enslavement is reified through their material objectification. The same special effect is employed in Die Nibelungen to depict the literal petrification of Alberich upon his slaying by the Aryan knight. As in Metropolis, the objectification of human bodies at the exteriority of modernity signifies a restoration of the natural order of white supremacy in that, as Bratton interprets, 'the "bad animals" are gone, and the Nibelungen as Untermenschen have become soulless creatures of stone' ${ }^{57}$ Yet in Metropolis, the Machine-Human incarnates a subversive danger in the clarity with which modernity's reliance upon coloniality is laid bare. Through the Machine-Human, Maria's spirit translates into the language of female objectification to explain the colonial origin of modernity, just as she had done before the 
workers in the Catacombs when she had used a language of liberation to tell the Legend of Babel. Pandemonium blazes through the audience, inflamed by her pagan declaration: 'we'll watch as the world goes to the devil!' Disillusioned with modernity, the revellers are possessed by the animus of coloniality. They carry the Machine-Human on their shoulders alongside Chinese lanterns, an orientalist chaos spilling out of Yoshiwara to storm the streets of the Upper City.

\section{[Figure 7]}

The film's famously unsatisfying conclusion restores harmony by repairing the border between coloniality and modernity. After initiating the erosion of modernity from within Yoshiwara, the possessed Machine-Human appears at its exterior exteriority in the Catacombs. She incites the workers to attack the foundations of modernity from its exterior by destroying the machines. In the same motion, she frees the women of the Workers' City from the domestic sphere to which they had been confined, who appear for the first time before the film's universalist white male gaze and consummate its apocalyptic fears. The foolishness of their insurgency is immediately evident when the Workers' City floods, attempting to demonstrate that coloniality relies upon patriarchal modernity and not the other way around after all. The mob of workers enters the Upper City for the first time, clashing with the tumultuous festivities pouring out from Yoshiwara. Order is restored only when Freder and Grot, who collaborate as the colonial administrator and indigenous ruler, identify the possessed Machine-Human. They exile her to the Catacombs and burn her at the stake for her occult transgression of patriarchal boundaries and the colonial difference. In the final scene, Grot and Fredersen shake hands at the 
steps of a European cathedral with the entire population of workers as their witness. They embrace a patriarchal modernist utopia exorcised of its latent animism.

[Figure 8]

\section{Conclusion}

The utopia presented at the end of Metropolis is as implausible as modernity without coloniality. Fredersen presents no promise of emancipation to the workers, even as he shakes hands with Grot to symbolise harmony between oppressor and oppressed. Just as the gardens of modernity are 'Eternal', so too is coloniality. The workers presumably no longer congregate in the Catacombs. They discard the animist understanding of their exploitation as driven by the insatiable hunger of a machinic spirit in favour of a secular rationalism. Mennel outlines the new ideology embraced by the workers of Metropolis: 'it is the spiritual connection of the heart between the hand and the brain, and the destruction of the atavistic and mystical-magical embodiment of capitalism that makes possible a modern, rational, and humane capitalism for the future' ${ }^{58}$ Coloniality is exterminated, or at least ethnically cleansed of the animism that has haunted modernity since its genesis. The unification of the Brain and the Hand, with the Heart as mediator, presents a perpetually peaceful modernity that became articulated as secular cosmopolitan ethics during late colonialism.

Despite its narrative absurdity, Metropolis has significantly exemplified and influenced modernity's civilisational project. Its utopian blueprint was, to some extent, intended as a vision to be enacted politically. Advertising material for the premiere promoted Metropolis as a tourist destination, reading: 'Metropolis, the city of the future, is the city of eternal social peace- the 
city of cities in which there is no animosity, no hatred, but only love and understanding' ${ }^{59}$ The peace comes through the total subjectification of the coloniser and objectification of the colonised. The colonised willingly surrender their agency and their bodies to the machinery of a modernity inaccessible to them. They forever resign themselves to the exteriority of modernity, an order eternalised with the fixity of racial differentiation. Müller raises the prospect that the 'heart' that Freder signifies 'is not a metaphor of love but rather the muscle that keeps the blood circulating' and maintains racial purity, suggesting that 'the body of the people is compared to the closed circulation of blood'. ${ }^{60}$ Indeed, the future that projects from the film's conclusion was later elucidated in numerous works of utopian science fiction, a genre that has long been pervaded with European visions for genocide, ethnic purity, and uniculturalism. In modernity's ultimate utopia, only the animus of the white male remains within the 'Brain', and all other agency is reified into dead labour in the form of the merely instrumental 'Hands'.

The pervasive coloniality that structures Metropolis suggests that modernity's exteriority may haunt all modernist texts. Its reliance upon whiteface to recode racial concerns into exclusively white spaces implies that a similar invisibilisation of coloniality is perhaps a dominant project of modernist visual art. Studies of gender in modernism should interrogate the agentic politics of patriarchal modernity and femininity/coloniality. Similarly, studies of capitalist dynamics in modernist art must consider the economy of modernity/coloniality and the spiritual dissonance generated by obscuring the coloniality of production. Further research to reconsider modernist texts from the perspective of the coloniality may seek traces of the colonial spectre in animist readings of commodity fetishism.

Foundational to the visual canon of modernity's mythology, Metropolis demonstrates that even when modernity is narrated from its interiority, it is shadowed by the spectre of coloniality. 
Its spectre phobically manifests as the white male desire for his own rehumanisation through the liberation of a feminised and colonised animism that carries within it the possibility that, eventually, the colonial difference will be dissolved. The phantamsic dystopia that haunts Metropolis threatens to disenchant the technological commodities fetishised and wielded by patriarchal modernity, and to release the spirits of dead labour within them. For hundreds of years, these spirits have borne the brutality of modernity and witness to its reliance upon the agencies that, during all that time, have flowed through women, the colonised, and the natural world.

\section{Figure Captions}

1. Orientalist representations of the colonised at Yoshiwara

2. The New Tower of Babel basks in white light

3. Workers kneel in the shadows of the Catacombs' primitivist architecture, where Maria gives a sermon while glowing white

4. Workers are pulled from the shadows towards the mouth of Moloch the machinic demon

5. Sigiriya, the ancient Sri Lankan rock fortress

6. The spirit of Maria possesses the Machine-Human at the base of a pentagram

7. Maria's pedestal of modernity/coloniality atop workers, before they turn to stone

8. Dark-coloured workers, led by Grot, approach the light-coloured and distinctly European cathedral

\footnotetext{
${ }^{1}$ Kenneth W Harrow (ed), African Cinema: Postcolonial and Feminist Readings, Trenton: Africa World Press, 1999; Sandra Ponzanesi and Marguerite Waller (eds), Postcolonial Cinema Studies, 2012, Oxon: Routledge. ${ }^{2}$ Stephen Zacks, 'The Theoretical Construction of African Cinema' in African Cinema: Postcolonial and Feminist Readings, Kenneth W Harrow (ed), Trenton: Africa World Press, 1999, p 10.

${ }^{3}$ Mitsuhiro Yashimoto, 'The Difficulty of being Radical: The Discipline of Film Studies and the Postcolonial World Order', boundary 2 18(3), 1991, p 243.

${ }^{4}$ Mignolo, 'The Many Faces', p 723.

${ }^{5}$ Walter Mignolo, 'The Many Faces of Cosmo-polis: Border Thinking and Critical Cosmopolitanism', Public Culture 12(3), 2000, p 722.
} 
${ }^{6}$ David T. Murphy, The Heroic Earth: Geopolitical Thought in Weimar Germany, 1918-1933, Kent, OH: Kent State University Press, 1997, p 191.

${ }^{7}$ R. L. Rutsky, 'The Mediation of Technology and Gender: Metropolis, Nazism, Modernism', New German Critique 60, 1993, pp 3-32.

${ }^{8}$ Andy Sawyer, 'More Than Metaphor: Double Vision in Lang's Metropolis', Foundation 64, 1995, pp 70-81.

${ }^{9}$ Aimé Césaire, Discourse on Colonialism, New York: Monthly Review, 2000, p 36.

${ }^{10}$ Tom Gunning, The Films of Fritz Lang: Allegories of Vision and Modernity, London: British Film Institute, 2000, p 82.

${ }^{11}$ Dennis Sweeny, “"Modernity” and the Making of Social Order in Twentieth-Century Europe', Contemporary European History 23(2), 2014, p 220.

${ }^{12}$ Geoff Eley, 'Conservatives and Radical Nationals in Germany: The Production of Fascist Potentials', in Fascists and Conservatives: The Radical Right and the Establishment in Twentieth-Century Europe, Martin Blinkhorn (ed), London: Routledge, 1990, pp 50-70.

${ }^{13}$ Istvan Csicsery-Ronay Jr, 'Science Fiction and Empire', Science Fiction Studies 30, 2003, pp 231-245.

${ }^{14}$ Anton Kaes, 'Metropolis (1927): City, Cinema, Modernity', in Expressionist Utopias: Paradise, Metropolis, Architectural Fantasy, Anton Kaes (ed), Berkeley: University of California Press, 2001, p 188.

${ }^{15}$ Mignolo, 'The Many Faces of Cosmo-polis', p 724.

${ }^{16}$ Deidre C. Byrne, 'The Top, the Bottom and the Middle: Space, Class and Gender in Metropolis', Literator 24(3), $2003, \mathrm{p} 3$.

${ }^{17}$ Alex McAuley, 'Savior of the Working Man: Promethean Allusions in Fritz Lang's Metropolis', in Classical Myth on Screen, Monica S Cyrino and Meredith E Safran (Eds), New York: Palgrave Macmillan, 2015, p 112.

${ }^{18}$ Walter Mignolo, 'The Geopolitics of Knowledge and the Colonial Difference', South Atlantic Quarterly 101(1), 2001, pp 60-61.

${ }^{19}$ Gabriela Stoicea, 'Re-Producing the Class and Gender Divide: Fritz Lang's Metropolis', Women in German Yearbook 22, 2006, p 32.

${ }^{20}$ Jürgen Müller, 'Babelsberg/Babylon: Fritz Lang's “Metropolis” Reinterpreted', in Berlin Metropolis: 1918-1933, Olaf Peters (ed), Munich: Prestel, 2015, p 154.

${ }^{21}$ Barbara Mennel, Cities and Cinema, New York: Routledge, 2008, p 44.

${ }^{22}$ Wendy Brown, 'In the account of Neoliberalism', lecture given at European Graduate School, 16 August 2016.

${ }^{23}$ Müller, 'Babelsberg/Babylon', p 156

${ }^{24}$ Stoicea, 'Class and Gender Divide', p 38.

${ }^{25}$ Sheri Berman, 'Civil Society and the Collapse of the Weimar Republic', World Politics 49(3), 1997, pp 401-429.

${ }^{26}$ McAuley, 'Savior of the Working Man', p 112.

${ }^{27}$ Walter Mignolo, 'Delinking: The Rhetoric of Modernity, the Logic of Coloniality and the Grammar of Decoloniality', Cultural Studies 21(2-3), 2007, pp 477-483.

${ }^{28}$ Eric Lott, 1997, 'The Whiteness of Film Noir', American Literary History 9(3), p 551.

${ }^{29}$ Barbara Mennel, 'White Law and the Missing Black Body in Fritz Lang's Fury (1936)', Quarterly Review of Film and Video 20(3), 2003, p 204.

${ }^{30}$ Susan P Bratton, 2000, 'From Iron Age Myth to Idealized National Landscape: Human-Nature Relationships and Environmental Racism in Fritz Lang's Die Nibelungen', Worldviews 4, pp 201-209.

${ }^{31}$ Peter Ruppert, 'Technology and the Construction of Gender in Fritz Lang's Metropolis', Genders 32, 2000.

${ }^{32}$ Kaes, 'Metropolis (1927)', p 180.

${ }^{33}$ Claudia Springer, Electronic Eros: Bodies and Desire in the Postindustrial Age, Austin, TX: University of Texas Press, 1996, p 154.

${ }^{34}$ Walter Mignolo, 'Coloniality at Large: The Western Hemisphere in the Colonial Horizon of Modernity', Michael Ennis (trans), New Centennial Review 1(2), 2001, p 27.

${ }^{35}$ Frantz Fanon, The Wretched of the Earth, London: Penguin, 2001, p 28.

${ }^{36}$ Andrew McCann, 'The Savage Metropolis: Animism, Aesthetics and the Pleasures of a Vanished Race', Textual Practice 17(2), 2003, p 324.

${ }^{37}$ Harry Garuba, 'On Animism, Modernity/Colonialism, and the African Order of Knowledge: Provisional Reflections', in Contested Ecologies: Dialogues in the South on Nature and Knowledge, Lesley Green (ed), Cape Town: HSRC, 2013, p 45.

${ }^{38}$ McCann, 'The Savage Metropolis', pp 323-326.

${ }^{39}$ Richard Murphy, 'Modernism and the Cinema: Metropolis and the Expressionist Aesthetic', Comparative Critical Studies 4, 2007, pp 106-108. 
${ }^{40}$ Steven Jacobs, 'Panoptic Paranoia and Phantasmagoria: Fritz Lang's Nocturnal City', in Spatial Turns: Space, Place, and Mobility in German Literary and Visual Culture, Jaimey Fisher and Barbara Mennel (eds), Amsterdam: Brill, 2010, pp 381-395.

${ }^{41}$ Daniel L Selden, "“Our films, their films": Postcolonial Critique of the Cinematic Apparatus', Postcolonial Studies 17(4), 2014, p 402.

${ }^{42}$ Caroline Rooney, African Literature, Animism, and Politics, London: Routledge, 2000, pp 13-23.

${ }^{43}$ Andreas Huyssen, After the Great Divide: Modernism, Mass Culture, Postmodernism, Bloomington: Indiana University Press, 1986, p 69.

${ }^{44}$ Michael Cowan, 'The Heart Machine: "Rhythm” and Body in Weimar Film and Fritz Lang's Metropolis', Modernism/modernity 14(2), 2007, pp 228-237.

${ }^{45}$ Gunning, The Films of Fritz Lang, p 80.

${ }^{46}$ Murphy, “"Our films, their films”, p 116.

${ }^{47}$ Russell Belk and Mariam Humayun, 'Object Agency and Extended Object', in Asia-Pacific Advances in Consumer Research Volume 11, Echo Wen Wan and Meng Zhang (eds), Duluth, MN: Association for Consumer Research, 2015, p 21.

${ }^{48}$ Eduardo Galeano, Open Veins of Latin America: Five Centuries of the Pillage of a Continent, Cedric Belfrage (trans), London: Latin America Bureau, 1997, pp 33-39.

${ }^{49}$ Kaes, 'Metropolis (1927)', p 180.

${ }^{50}$ Huyssen, After the Great Divide, p 71.

${ }^{51}$ Heidi J Nast, 'The Machine-Phallus: Psychoanalyzing the Geopolitical Economy of Masculinity and Race', Psychoanalytic Inquiry 35(8), 2015, p 776.

${ }_{52}$ Huyssen, After the Great Divide, p 81.

${ }^{53}$ Rooney, African Literature, p 21.

${ }^{54}$ Huyssen, After the Great Divide, p 75.

${ }_{55}^{55}$ Cowan, 'The Heart Machine', p 240.

${ }^{56}$ McCann, 'The Savage Metropolis', p 329.

${ }^{57}$ Bratton, 'From Iron Age Myth', p 204.

${ }^{58}$ Mennel, Cities and Cinema, p 41.

${ }^{59}$ Kaes, 'Metropolis (1927)', p 176.

${ }^{60}$ Müller, 'Babelsberg/Babylon', p 154. 